\title{
Drought Stress Responses of Sunflower Germplasm Developed after Wide Hybridization
}

\author{
Roumiana Dimova Vassilevska-Ivanova ${ }^{1}$, Lydia Shtereva ${ }^{1}$, Ira Stancheva ${ }^{2}$, Maria Geneva ${ }^{2}$ \\ ${ }^{I}$ Department of Applied Genetics and Biotechnology, Institute of Plant Physiology and Genetics, Bulgarian Academy of Sciences, Acad. G. \\ Bonchev str., Bl. 21, 1113 Sofia, Bulgaria \\ ${ }^{2}$ Department of Plant-Soil Minerals Nutrition and Water Relation, Institute of Plant Physiology and Genetics, Bulgarian Academy of \\ Sciences, Acad. G. Bonchev str., Bl. 21, 1113 Sofia, Bulgaria
}

A R T I C L E I N F O

Article history:

Received 12 May 2016

Accepted 20 July 2016

Available online, ISSN: 2148-127X

Keywords:

Antioxidants

Helianthus annuus $\mathrm{L}$

Tithonia rotundifolia

Verbesina encelioides

Wide hybridization

${ }^{*}$ Corresponding Author:

E-mail: ru_vas_bg@yahoo.com

A B S T R A C T

Response of sunflower germplasms viz. cultivated sunflower $H$. annuus and two breeding lines $H$. annuus x $T$. rotundifolia and $H$. annuus $\times$ $V$. encelioides developed after wide hybridization were used for identification of drought tolerant sunflower genotypes at the seedling growth stage. Three water stress levels of zero (control), -0.4 , and $-0.8 \mathrm{MPa}$ were developed using polyethyleneglycol-6000 (PEG-6000). Physiological and biochemical stress determining parameters such as root and shoots length, fresh weight, antioxidant enzyme activities (superoxide dismutase (SOD), catalase (CAT), guaiacol peroxidase (GPO), ascorbate peroxidase (APX) and antioxidant metabolite content (total antioxidant capacity, total phenols and total flavonoids content) were compared between seedlings of all three genotypes. Results revealed that sunflower genotypes have similar responses at two osmotic potentials for shoot and root length and fresh weight. The data also showed that drought stresss could induce oxidative stress, as indicated by the increase level of ascorbate peroxidase and guaiacol peroxidase at $-04 \mathrm{MPa}$ in $H$. annuus cv 1114. Although the activity of ascorbate peroxidase and guaiacol peroxidase was differentially influenced by drought, the changes of antioxidant enzyme activities such as catalase, superoxide dismutase, guaiacol peroxidase, and ascorbate peroxidase subjected to drought stress follow a similar pattern in both breeding lines, indicating that similar defense systems might be involved in the oxidative stress injury in sunflowers. Increase in content of phenols and flavonoids were detected for all three genotypes under stress, which showed that these were major antioxidant metabolites in scavenging cellular $\mathrm{H}_{2} \mathrm{O}_{2}$.

\section{Introduction}

The sunflower (Helianthus annuus L.) is one of the major oil crops world-wide, and is currently grown on five continents (Diaz-Zorita et al., 2003). In Bulgaria, sunflower is a crop of economic significance as a main source of edible vegetable oil (Zlatanov et al., 2008). Although sunflower is categorized as a low to medium drought sensitive crop (Rauf, 2008) its production suffers substantially from drought stress that is one of the major abiotic factors limiting productivity of cultivated crops (Ashraf, 2010; Tuteja et al., 2012).

Drought stress has caused an inhibition of growth and development, reduction in photosynthesis, respiration and protein synthesis in sensitive species (Meloni et al., 2003; Ashraf and Foolad, 2007; Tuteja et al., 2012). Like other abiotic stresses, drought stress also leads to oxidative stress through an increase in reactive oxygen species (ROS), such as superoxide $\left(\mathrm{O}_{2}{ }^{-}\right)$, hydrogen peroxide $\left(\mathrm{H}_{2} \mathrm{O}_{2}\right)$ and hydroxyl radicals $(\mathrm{OH} *)$ (Alscher et al., 1997; Mittler, 2002; Neill et al., 2002). These ROS are highly reactive and can alter normal cellular metabolism through oxidative damage to lipids, proteins and nucleic acids (Alscher et al., 1997; Imlay, 2003). Plants with high level of antioxidants, either constitutive or induced, have been reported to have greater resistance to the oxidative damage. The degree of yield reduction resulting from drought stress depends on the growth stage of the crop (germination, seedling, and flowering), the severity of the drought, and drought tolerance of the plant genotype (Ahmad et al., 2009). Therefore, it is essential to develop and identify drought-tolerant germplasm that will allow an expansion of the cultivated area.

In sunflower, wide hybridization (interspecific and intergeneric) is a useful technique for increase the genetic variations in hybridizing population and so, for development of new genotypes with desirable agronomic traits (Faure et al., 2002; Rönicke et al., 2004; Breton et al., 2010; Breton et al., 2012; Vassilevska-Ivanova et al., 2013; Vassilevska-Ivanova et al., 2014a). For drought tolerance breeding, wild annual species $H$. argophyllus has been a potential source for genes for drought 
resistance and has therefore extensively used by sunflower breeders (Griveau et al., 1998; Petcu and Pâcureanu, 2011). There have been few studies of hybridization between cultivated sunflower $H$. annuиs and species from related genera of Asteraceae family (Reyes-Valdés et al., 2005; Vassilevska-Ivanova and Naidenova, 2005; Vassilevska-Ivanova et al., 2013; Vassilevska-Ivanova et al., 2014a; Vassilevska-Ivanova et al., 2015). In this study, we included two advanced breeding line developed after conventional crosses: Helianthus annuus $\times$ Tithonia rotundifolia (Miller) S. F. Blake and Helianthus annuus $\times$ Verbesina encelioides (Cav) Benth. \& Hook f. ex A. Gray. Both wild species were included in our sunflower research program with objective of producing and evaluating new intergeneric hybrids that provide novel combination of traits useful for plant breeding. In particular, the program combines interest from both plant breeding and academic research in the use of wide hybridization for transferring desirable traits from wild relatives to cultivated sunflower.

T. rotundifolia (Mexican sunflower) is a widespread annual species member of the tribe Heliantheae within Asteraceae; it exhibits an herbaceous habit and diploid chromosome number $(\mathrm{n}=17)$. $V$. encelioides (Golden crownbeard) is a well-branched erect herbaceous annual (Wagner, 1990) with diploid chromosome number $(n=22)$. Both species are native to the North and Central America and Mexican Plateau (La Duke, 1982) where they occupy arid and disturbed habitats. The plants do not require large amounts of water and they considered drought tolerant (Singh and Malik, 2012). However, to the best of our knowledge, data indicating drought tolerance genes in $T$. rotundifolia or $V$. encelioides have not been presented. Here, we seek to expand information on the possible capability of these species to improve drought tolerance of sunflower via hybridization, by studying physiological and biochemical parameters under stress simulated by polyethylene glycol.

Although previous research discussed wide hybridization in sunflower as one of the most important strategies having the potential to combine useful traits of both parents that could not be achieved by crossing within a single species (Faure et al., 2002; Rönicke et al., 2004; Breton et al., 2010; Breton et al., 2012; VassilevskaIvanova et al., 2013; Vassilevska-Ivanova et al., 2014a), so far there has been no side-by-side comparison of hybrid plants with regard to their origin on drought stress. Therefore, we have analyzed the behavior of three different sunflower genotypes-cultivated $H$. annuus and two advanced lines developed after intergeneric hybridization with species of related genera Verbesina and Tithonia in the early developmental stages under experimental drought conditions. The response of sunflower plants was characterized with reference to water deficit on growth parameters, antioxidant enzyme activities such as superoxide dismutase (SOD), catalase (CAT), guaiacol peroxidase (GPO), and ascorbate peroxidase (APX) as well as the antioxidant metabolites content - total phenols and flavonoids, and total antioxidant capacity during stress.

\section{Materials and methods}

\section{Plant Materials, Growth Conditions and Stress} Treatments

Three sunflower (Helianthus annuus L.) genotypes with diversified genetic background were chosen on the basis of speculation of the potential of wild Helianthus species to impact the adaptation of the introgressed hybrids under drought conditions. Seeds of $H$. annuus L. cultivar 1114 and two advanced intergeneric lines $H$. annuus $\times$ Tithonia rotungifolia and $H$. annuus $\times$ Verbesina encelioides were used in this study. These genotypes were developed at the Institute of Plant Physiology and Genetics, Bulgarian Academy of Sciences, Sofia, following a research program using the potential of wide hybridization for producing and evaluating new sunflower germplasms. The intergeneric line Helianthus $\times$ Verbesina originated from pollination of cytoplasmic male sterile (cms) line HA89 (female), a public oilseed sunflower inbred maintainer line released by US Department of Agriculture-Agricultural Research Service, with bulked pollen from wild annual Verbesina encelioides (male). The cms line L 1234 of H. annuus, released by Dobrudza Institute of Wheat and Sunflower, Bulgaria was pollinated with bulked pollen from $T$. rotundifolia. The populations of both $V$. encelioides and T. rotundifolia species were grown from seeds originally obtained from the Botanical Garden of Lisbon, Portugal. The crosses were made by conventional hybridization method. Each experiment was carried out on flower heads which had been protected from foreign pollen by bagging. First generation hybrid plants were verified using morphological and cytological methods, and $F_{1}$ hybrids were back-crossed to the common sunflower to obtain $\mathrm{BC}_{1}$ and $\mathrm{BC}_{2}$. The main agronomic and morphological characteristics of these plants as well as their inheritance were described in our previous works (VassilevskaIvanova et al., 1999; Vassilevska-Ivanova and Tcekova, 2002). Seeds from advanced plant generations were produced after self-pollination under a bag. They were stored dry in paper bags at $5^{\circ} \mathrm{C}$ for at least 9 months before the experiments and were non-dormant.

The genotypes were screened for drought tolerance at seedling stage in hydroponic system using the standard protocol as previously described (Vassilevska-Ivanova et al., 2000). After germination, when cotyledons fully emerged, the healthy and uniform seedlings were transferred to $600 \mathrm{~mL}$ plastic beakers filled with halfstrength Hoagland's solution (Hoagland and Arnon, 1950) and grown in a controlled growth chamber "Forma Scientific" model 3744 at $25 \pm 2{ }^{\circ} \mathrm{C}$ with a 16-h light $(250$

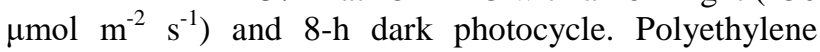
glycol-6000 (PEG-6000) was used as a drought stimulator. Three drought stress levels with different osmotic potentials of zero (control), $-0.4(10 \% \mathrm{w} / \mathrm{v})$ and $0.8(20 \% \mathrm{w} / \mathrm{v}) \mathrm{MPa}$ were generated by dissolving PEG to half-strength Hoagland's solution (Michel and Kaufmann, 1973). The drought stress period created by PEG-6000 was 3 days. Each set of experiments was performed three times. 
At the end of the experiment (14 days), the plants were harvested. For phenotypic observation plant shoots and root length as well as their fresh weight was recorded in both normal (control) and drought conditions.

\section{Estimation of Enzyme Activity}

Enzyme extracts were prepared by homogenizing plants tissue in a pre-chilled mortar in $20 \mathrm{ml}$ chilled extraction buffer ( $\mathrm{pH} 7.8$ ). Extracts were then centrifuged at $12000 \mathrm{~g}$ for $30 \mathrm{~min}$ at $5^{\circ} \mathrm{C}$. Enzyme assays were conducted immediately following extraction.

Superoxide dismutase (SOD) (EC 1.15.1.1) was measured by photochemical method described by Giannopolitis and Ries (1977). Assays were carried out under illumination. One unit of SOD activity was defined as the amount of enzyme required to cause $50 \%$ inhibition of the rate of p-nitro blue tetrazolium chloride reduction at $560 \mathrm{~nm}$.

Catalase (CAT) (EC 1.11.1.6) activity was assayed in a method following Beers and Sizer (1952) with minor modifications. Activity was determined by following decomposition of $\mathrm{H}_{2} \mathrm{O}_{2}$ (extinction coefficient, $39.4 \mathrm{mM}^{-1}$ $\mathrm{cm}^{-1}$ ) at $240 \mathrm{~nm}$. The enzyme activity was expressed in catalytic units-mmol $\mathrm{H}_{2} \mathrm{O}_{2} \mathrm{~mL}^{-1} \mathrm{~min}^{-1}$ per mg protein.

Guaiacol peroxidase (GPO) (EC 1.11.1.7) activity was determined according to Urbanek et al. (1991). The oxidation of guaiacol in the presence of $\mathrm{H}_{2} \mathrm{O}_{2}$ was measured as the increase in absorbance recorded at 470 $\mathrm{nm}$. The enzyme activity was expressed as nmol $\mathrm{H}_{2} \mathrm{O}_{2} \mathrm{mg}$ protein $^{-1} \min ^{-1}$ (Plewa et al., 1991).

Ascorbate peroxidase (APX) (EC 1.11.1.1) activity was determined measured according to the method of Nakano and Asada (1981). The concentration of oxidized ascorbate was calculated by the decrease in absorbance at $290 \mathrm{~nm}$. Enzyme activity was quantified using the molar extinction coefficient for ascorbate $\left(2.8 \mathrm{mM}^{-1} \mathrm{~cm}^{-1}\right)$, and was expressed as moles of ascorbate oxidized per milligram of protein per minute (McKersie and Leshem 1994).

Soluble protein content was determined by the method of Bradford (1976) using bovine serum albumin as a standard.

\section{Estimation of Antioxidant Activity}

The total antioxidant capacity (free radical scavenging activity) as well as the presence of the antioxidantsphenols and flavonoids was measured in fresh leaves from ten plants (bulked probe) of the all three genotypes. All methods used were previously described (Stancheva et al., 2011). The total antioxidant capacity was measured from bleaching of the purple coloured methanol solution of free stable radical (2, 2-diphenyl-1-picryl-hydrasyl, DPPH') by the method of Tepe et al. (2006). DPPH ${ }^{*}$ is a stable radical with a maximum absorption at $517 \mathrm{~nm}$ that can readily undergo reduction by an antioxidant. Radical scavenging activity was calculated as the inhibition \% of DPPH scavenging by samples, using the following equation:

$\%$ antioxidant activity $(\mathrm{I})=\left(\mathrm{A}_{\text {blank }}-\mathrm{A}_{\text {sampe }} / \mathrm{A}_{\text {blank }}\right) \times 100$
Where $A_{\text {blank }}$ is the absorbance of the control sample (containing all reagents except the test compound), and $\mathrm{A}_{\text {sample }}$ is the absorbance of plant extracts.

The concentration of total phenols in the extracts was measured spectrofotometrically using the Folin-Ciocalteu method and calculated as caffeic acid equivalents (Pfeffer et al., 1998). The results were expressed in milligrams of caffeic acid per gram of dry weight. The total flavonoids content was measured spectrofotometrically by method of Zhishen et al. (1999) using a standard curve with catechin as the standard. Total flavonoids content was expressed in milligrams of catechin equivalents per gram of dry weight.

\section{Statistical Analysis}

Twenty plants were raised for each treatment and all the experiments were repeated twice. Data were subjected to one-way ANOVA analysis of variance for comparison of means, and significant differences were calculated according to Fisher LSD test at the 5\% level using a statistical software package (Statigraphics Plus, version 5.1 for Windows). Data were reported as means \pm standard error. Standard errors were represented as vertical bars, which were the mean of three values $(n=3)$, and similar letters in figures represent non-significant differences among the treatments within each genotype. The figures were performed with the OriginPro 8 SRO, Company OriginLab Corporation program package.

\section{Results}

Effect of Drought Stress on Seedling Growth in The Three Sunflower Genotypes

The results revealed that the root and shoot length as well as the fresh weight were strongly affected by PEGmediated water stress. Increased PEG concentration caused a decrease in these characters as the response to drought varied among genotypes.

Root and shoot growth was followed by measuring length and fresh weight (FW) under PEG treatment. Increasing concentrations of PEG from -0.4 to $-0.8 \mathrm{MPa}$ progressively reduced root and shoot length in all three sunflower genotypes as the lowest values were recorded at $-0.8 \mathrm{MPa}$ (Table 1). The comparison between the effects of PEG at iso-osmotic concentrations showed that $H$. annuus as well as the hybrid seeds of both lines were inhibited almost to the same degree.

There was significant reduction in the fresh weight of shoots and roots of the cultivar 1114 and hybrids as the water stress had a stronger effect on the cultivated genotype (Table 1). Maximum reduction (51\%) of the fresh weight of roots of $H$. annuus was observed at higher osmotic potential $(-0.8 \mathrm{MPa})$ compared to that of the controls. Similar trend of reduction (about $45 \%$ to $53 \%$ ) down from the control was established for shoot fresh weight of all three genotypes. The inhibitory effect of PEG treatments on the shoots fresh weight was higher than those of the roots (Table 1). 
Table 1 Effects of drought stress on root and shoot growth responses (mean length per seedling in $\mathrm{cm}$ ) and fresh weight (g per plant) of cultivated sunflower H. annuus cv. 1114 and two intergeneric lines $H$. annuus $\times$ Tithonia rotundifolia and $H$. annuus $\times$ Verbesina encelioides; percentage control values are given in parenthesis

\begin{tabular}{|c|c|c|c|c|}
\hline \multirow[b]{2}{*}{ Plant organs } & \multirow{2}{*}{$\begin{array}{c}\text { Osmotic } \\
\text { potential } \\
(\mathrm{MPa})\end{array}$} & \multicolumn{3}{|c|}{ Genotypes } \\
\hline & & H. annuus cv 1114 & $\begin{array}{l}\text { H. annuus } \times \mathrm{T} \text {. rotundifolia } \\
\text { Length, } \mathrm{cm}\end{array}$ & H. annuus $\times$ V. encelioide \\
\hline \multirow{3}{*}{ Root } & 0 & $20.9(100) \pm 2.11^{\mathrm{a}}$ & $17.2(100) \pm 2.26^{\mathrm{a}}$ & $20.7(100) \pm 2.17^{\mathrm{a}}$ \\
\hline & -0.4 & $17.9(85.6) \pm 2.14^{\mathrm{ab}}$ & $14.6(84.9) \pm 1.50^{\mathrm{ab}}$ & $16.6(80.2) \pm 1.41^{\mathrm{ab}}$ \\
\hline & -0.8 & $14.8(70.8) \pm 1.47^{\mathrm{bc}}$ & $12.8(74.4) \pm 1.80^{\mathrm{bc}}$ & $13.0(62.8) \pm 1.52^{\mathrm{c}}$ \\
\hline \multirow{3}{*}{ Shoot } & 0 & $12.8(100) \pm 2.08^{\mathrm{a}}$ & $8.2(100) \pm 1.10^{\mathrm{a}}$ & $9.4(100) \pm 1.72^{\mathrm{a}}$ \\
\hline & -0.4 & $11.0(85.9) \pm 1.51^{\mathrm{ab}}$ & $6.2(75.6) \pm 0.73^{b}$ & $8.3(88.3) \pm 1.33^{\mathrm{ab}}$ \\
\hline & -0.8 & $8.5(66.4) \pm 1.04^{\mathrm{c}}$ & $4.9(59.7) \pm 0.82^{c}$ & $6.1(64.9) \pm 0.63^{c}$ \\
\hline \multicolumn{5}{|c|}{ Fresh weight, g/plant } \\
\hline \multirow{3}{*}{ Root } & 0 & $0.7591 \pm 0.03^{\mathrm{a}}$ & $0.3377 \pm 0.04^{\mathrm{a}}$ & $0.2684 \pm 0.01^{\mathrm{a}}$ \\
\hline & -0.4 & $0.5971 \pm 0.04^{\mathrm{b}}$ & $0.2843 \pm 0.02^{\mathrm{b}}$ & $0.2443 \pm 0.01^{\mathrm{b}}$ \\
\hline & -0.8 & $0.3874 \pm 0.04^{\mathrm{c}}$ & $0.2130 \pm 0.03^{\mathrm{c}}$ & $0.1817 \pm 0.01^{\mathrm{c}}$ \\
\hline \multirow{3}{*}{ Shoot } & 0 & $1.0642 \pm 0.08^{\mathrm{a}}$ & $0.4353 \pm 0.04^{\mathrm{a}}$ & $0.3252 \pm 0.03^{\mathrm{a}}$ \\
\hline & -0.4 & $0.6288 \pm 0.05^{\mathrm{b}}$ & $0.3927 \pm 0.02^{\mathrm{ab}}$ & $0.2311 \pm 0.01^{\mathrm{b}}$ \\
\hline & -0.8 & $0.5059 \pm 0.04^{\mathrm{bc}}$ & $0.2305 \pm 0.01^{\mathrm{c}}$ & $0.1452 \pm 0.01^{\mathrm{c}}$ \\
\hline
\end{tabular}

*Means $(\mathrm{n}=3) \pm$ SE; Values with different superscripts $(\mathrm{a}-\mathrm{c})$ are significantly different $(\mathrm{P}<0.05)$

\section{Determination Level of CAT, SOD, GPO, and APX}

Antioxidant enzymes are the first response mechanism against environmental stress. As such, their activity profiles are important in the evaluation of tolerance mechanisms. Fig. 1 shows the effect of drought stress on the activity of antioxidant enzymes participating in the scavenging of ROS in examined sunflower genotypes. CAT activity decreased under drought treatment in all of the genotypes compared to the activities occurring in the control plants (Fig. 1). The greatest decrease was observed in $H$. annuus $\times V$. encelioides hybrid plants treated with $-0.4 \mathrm{MPa}$ PEG.

The pattern of leaf-SOD activity in plants of the all three sunflower genotypes was different (Fig. 1). In the control treatment, SOD-activities were statistically higher in $H$. annuus genotype than activities recorded in intergeneric lines. There was a uniform decrease in all three genotypes with the increase in PEG-concentration as compared to controls (Fig. 1). The greatest decrease was observed in $H$. annuus cv 1114 and hybrid line $H$. annuus $\times T$. rotundifolia treated with $-0.4 \mathrm{MPa}$ PEG compared with the control.

The guaiacol peroxidase (GPO) activity in each sunflower genotype under different water stress was evaluated. GPO activities for both intergeneric control lines were higher than that for $H$. annuus cv 1114 control plants (Fig. 1). An increase in GPO activity was established at both PEG concentrations (Fig. 1). However, under the same drought conditions, the GPO activity of both hybrid lines decreased compared to the controls.

Ascorbate peroxidase (APX) is another important enzyme that is effective in ascorbate-glutathion cycle. No significant increase was noticed in APX activity in $H$. annuus cv 1114 genotype under drought stress (-0.4 MPa PEG), whereas a decline in the activity was observed in both lines compared with their respective activities in the controls (Fig. 1). A sharp decrease in APX activity was found in $H$. annuus $\times V$. encelioides plants grown in the presence of PEG compared with plants grown under control conditions.

Determination Level of Phenols, Flavonoids, and DPPH

The effect of water stress on the content of examined antioxidant metabolites is given in Fig. 2. In the all three sunflower genotypes, levels of phenols significantly increased in plants exposed to - $0.8 \mathrm{MPa}$ PEG compared to the control (Fig. 2). In H. annuus cv 1114 and H. annuus $\times T$. rotundifolia seedlings, phenols content decreased in response to water stress at $-04 \mathrm{MPa}$ osmotic potential. Phenols content increased in plants of $H$. annuus $\times V$. envclioides line grown in PEG concentration of $-0.4 \mathrm{MPa}$ compared with levels recorded in control plants (Fig. 2). Analysis of flavonoids metabolism in three sunflower genotypes subjected to water stress revealed a number of similarities between these genotypes. The most striking of these similarities was an increase in the amount of total flavonoids level of plants grown in the presence of -0.8 PEG (Fig. 2). There was no significant difference in total antioxidant capacity as measured by the DPPH radical scavenging method between cultivated sunflower and $H$. annuus $\times$ T. totundifolia and $H$. annuus $\times V$. encelioides lines (Fig. 2).

\section{Discussion}

During the last years, there has been an increasing interest in identifying attributes which contribute to drought resistance and which can be used as selection criteria in crop breeding programs. In this sense, many examples of oxidative stress and antioxidant defense mechanism in $H$. annuus subjected to drought (Kaya et al., 2006; Rauf et al., 2008; Ahmad et al., 2009; Petcu and Pâcureanu, 2011) have been reported. However, there have been limited studies concerning the response of sunflower genotypes developed after wide (interspecific or intergeneric) hybridization (Vassilevska-Ivanova et al., 
2014b). In this paper we have presented two genetically stable lines that have intermediate characteristics between both parents and will likely be useful in sunflower breeding. To our best knowledge, the present study is the first attempt to evaluate the intergeneric sunflower lines under drought stress.

The most prominent effect of water stress was the stunted growth in a concentration-dependent manner, represented by reduced seedling length (roots and shoots), and fresh weight, respectively. Reduction in seedling growth is the result of restricted cell division and enlargement, as drought stress directly reduces growth by deceasing cell division and elongation (Anjum et al., 2011; Claeys and Inzé, 2013). In the current study, a substantial decrease of shoot and root fresh weight resulted from the PEG-mediated water deficit was observed at -0.8 MPa as drought suppressed shoot growth more than root growth (Table 1). The results are in accordance with Baloğlu et al., (2012); Csiszár et al., (2012); Marcińska et al., (2013). This pattern was evident in all three sunflower genotypes as the reduction in the values of seedling growth parameters was similar (to varying degrees). However, at $-0.4 \mathrm{MPa}$ osmotic potential, the differences among genotypes were certainly prominent, a fact that could be the result of genetic differences. It appears that, under condition of none or minimal water stress, the seedling response to drought was probably more influenced by the genetic background. These observations are in agreement with some reports demonstrating that drought response of sunflower (Helianthus sp.) is strongly affected by genetic factors
(Turhan and Baser, 2004; Ahmad et al., 2009; Ŝcorić, 2009; Oraki et al., 2012; Baloĝlu et al., 2012).

Drought stress is inevitably associated with increased oxidative stress due to enhanced accumulation of ROS, particularly $\mathrm{O}_{2}^{-}$and $\mathrm{H}_{2} \mathrm{O}_{2}$ in chloroplasts, mitochondria, and peroxisomes. As a result, the induction of antioxidant enzyme activities is a general adaptation strategy which plants use to overcome oxidative stresses (Foyer and Noctor, 2003). The ability of plants to overcome the effect of oxidative stress partly relies on the induction of $\mathrm{SOD}$, the major scavenger of $\mathrm{O}^{\circ-}$ that catalyzes the conversion of superoxide radical into hydrogen peroxide (Lin et al., 2000). $\mathrm{H}_{2} \mathrm{O}_{2}$ is then scavenged of other downstream antioxidant enzymes such as CAT and different classes of peroxidases (Alscher et al., 2002). GPO and APX play a key role in the ascorbateglutathione cycle by reducing $\mathrm{H}_{2} \mathrm{O}_{2}$ to water at the expense of oxidizing ascorbate to monodehydroascorbate (MDHA) (Cakmak et al., 1993). In our experiment, the results did not show elevation of SOD and CAT activity in the sunflower genotypes exposed to drought stress (Fig. 1). APX enzyme activity increased as result of moderate drought $(-0.4 \mathrm{MPa})$ in the cultivated sunflower $H$. annuus cv 1114, only. The increase of GPO activity also was observed under same conditions in $H$. annuus which might lead to their higher protection against water deficit. GPO pattern is in correspondence with total antiradical activity. Some previous studies reported the increased GPO activity under drought stress conditions in various plants like sunflower (Gunes et al., 2008), liquorice (Pan et al., 2006) and poplar (Xiao et al., 2008).

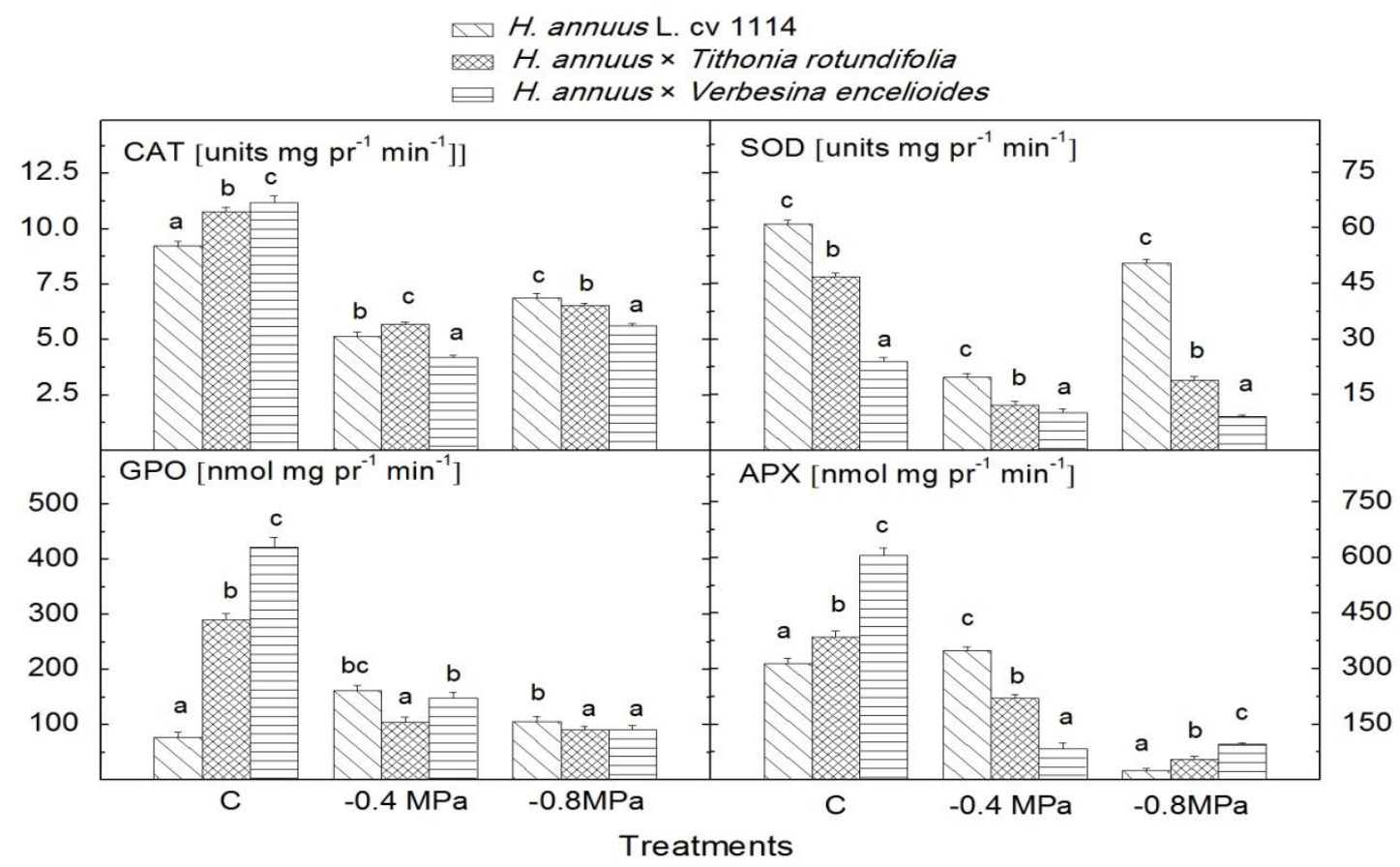

Fig. 1 Activity of antioxidant enzymes catalase (CAT), superoxide dismutase (SOD), guaiacol peroxidase (GPO), and ascorbate peroxidase (APX) in the leaves of cultivated sunflower H. annuus cv. 1114 and two intergeneric lines $\mathrm{H}$. annuus $\times$ Tithonia rotundifolia and $\mathrm{H}$. annuus $\times$ Verbesina encelioides grown at different levels of drought. Values are means $\pm \mathrm{SE}, \mathrm{n}=3$; different letters indicate significant differences assessed by Fisher LSD test $(\mathrm{P} \leq 0.05)$ after performing ANOVA multifactor analysis 


\section{H. annuus L. CV 1114 \\ H. annuus $\times$ Tithonia rotundifolia \\ H. annuus $\times$ Verbesina encelioides}

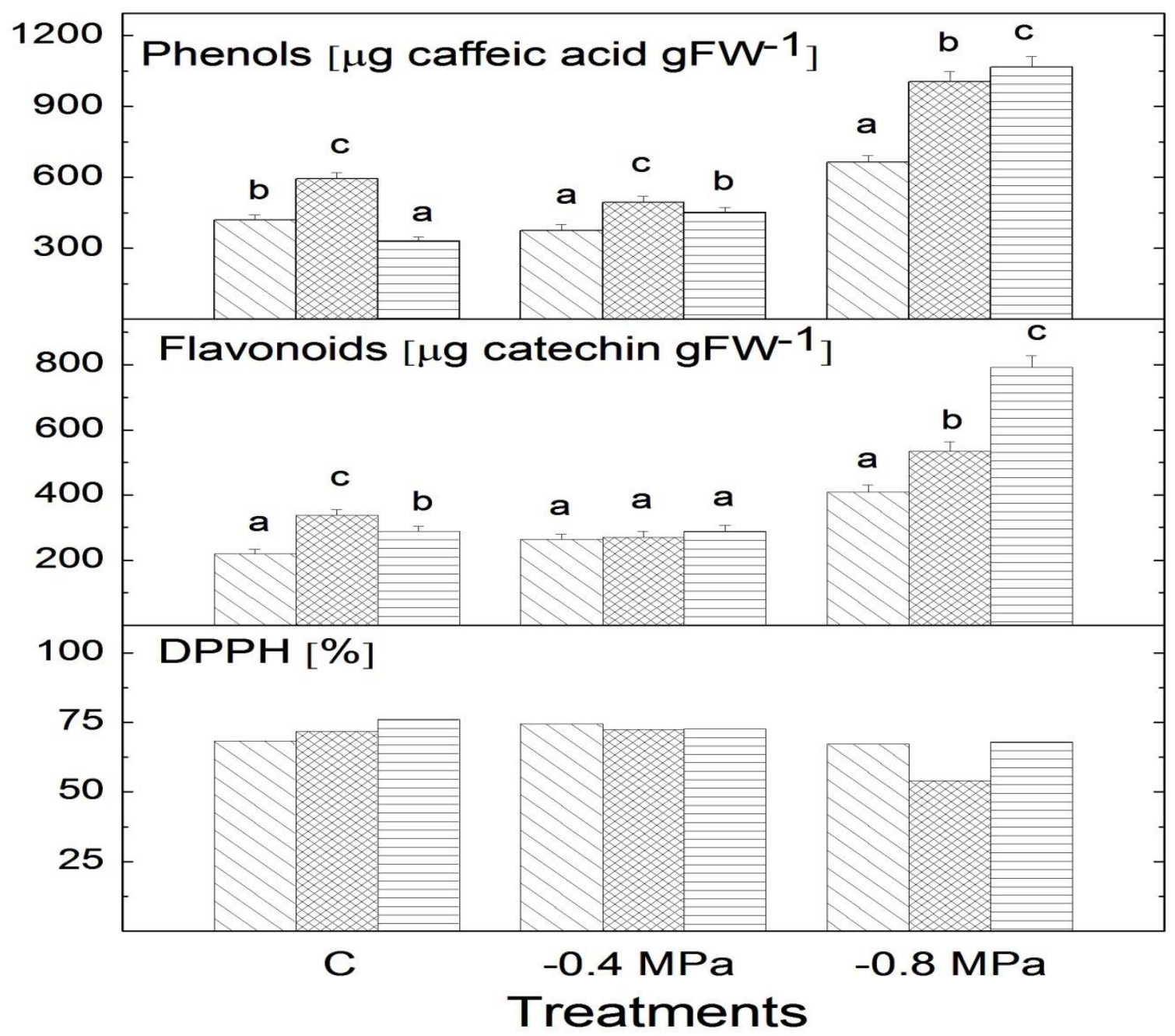

Fig. 2 Content of total phenols and flavonoids and total antioxidant capacity in the leaves of cultivated sunflower H. annuus cv. 1114 and two intergeneric lines H. annuus $\times$ Tithonia rotundifolia and $\mathrm{H}$. annuus $\times$ Verbesina encelioides grown at different levels of drought. Values are means $\pm \mathrm{SE}, \mathrm{n}=3$; different letters indicate significant differences assessed by Fisher LSD test $(\mathrm{P} \leq 0.05)$ after performing ANOVA multifactor analysis

The decline in CAT activity is regarded as a general response to many stresses (Bakalova et al., 2004; Guo et al., 2006; Pan et al., 2006; Gunes et al., 2008). The reduction of CAT activity is supposedly due to the inhibition of enzyme synthesis or change in the assembly of enzyme subunits under stress conditions. It may also be associated with degradation caused by induced peroxisomal proteases or may be due to the photoinactivation of the enzyme. The increase in GPO enzyme activity might be considered as a key point for the decomposition of $\mathrm{H}_{2} \mathrm{O}_{2}$, especially under CAT inactivation. The protective effects of plant constituents are due to the presence of several components which have distinct mechanisms of action - low molecular weight compounds such as vitamins, flavonoids and other phenolic compounds. Flavonoids and phenolic substances isolated from wide range of vascular plants, act in plants as antioxidants, antimicrobials, photoreceptors, visual attractors, feeding repellents and for light screening (Pietta, 2000). According to our results, the content of phenols and flavonoids increased in the all three genotypes at higher water stress (-0.8 MPa) (Fig. 2). Based on these findings we could suggest that antioxidant defense under conditions of our experiment is determined by the phenolic compounds-total phenols and flavonoids.

According to Benavente-García et al. (2000) radical scavenging activity of plant extracts depends on the amount of polyphenolic compounds in the extracts. It has 
already been reported that the antioxidant mechanism of flavonoids may also come from the interaction between transition-metal ions and flavonoids to produce complexes that keep the metal ions from their participation in free-radical generation (Zhishen et al., 1999). The beneficial effects of certain phenols or their potential antioxidant properties, especially when these compounds are present in large quantities in foods, resulted in supplementation of natural antioxidants through effective, balanced diet, which is of great importance to consumers. Contents of flavonoids and other phenolic substance have been suggested to play a preventive role in the development of cancer and heart disease (Kahkonen et al., 1999).

Recent studies of wide hybridization in sunflower have shown that the union of two distinct genomes within a new hybrid individual can provide a source of phenotypic novelty associated with specific performance (Riesenberg and Willis, 2007; Hegarty et al., 2008). It can be said from the results obtained here that a number of features of the sunflower genotypes studied are directly affected by PEG-mediated water stress. Although all three genotypes had similar responses to the PEG-exposure, our results demonstrate that there is a substantial degree of variation at seedling stage as well as the antioxidant enzymes activity and content of antioxidant metabolites under drought stress. Differences between genotypes in the antioxidant enzymes activity (CAT, SOD, GPO and APX) have been evident still at the control plants. Increased levels of phenols and flavonoids were observed, which showed that these were major antioxidant metabolites in scavenging cellular $\mathrm{H}_{2} \mathrm{O}_{2}$. Genotypic differences in drought tolerance could be, at least in part, attributed to the ability of plants to acclimate and induce different defense mechanisms under severe water stress in sunflower. These observations suggest to us that the induced responses are mostly dependent on the genetic potential of the genotype.

\section{Conflict of Interest}

The authors declare no conflict of interest.

\section{References}

Abu-Jdayil B, Mohameed H. 2002. Experimental and modeling studies of flow properties of concentrated yogurt as affected by the storage time, J Food Eng, 52, 359-365.

Ahmad S, Ahmad R, Ashraf MY, Ashraf M, Waraich EA. 2009 Sunflower (Helianthus annuus L.) response to drought stress at germination and seedling growth stages. Pak. J. Bot., 41:647654.

Alscher RG, Donahue JL, Cramer CL. 1997. Reactive oxygen species and antioxidants: relationships in green cells. Physiol. Plantarum, 100(2):224-233.

Alscher RG, Erturk N, Heath LS. 2002. Role of superoxide dismutases (SODs) in controlling oxidative stress in plants. $\mathrm{J}$. Exp. Bot., 53(372):1331-1341.

Anjum SA, Xie XY, Wang LC, Saleem MF, Man C, Lei W. 2011. Morphological, physiological and biochemical responses of plants to drought stress. Afr. J. Agricul. Res., 6(9):2026-2032.

Ashraf M. 2010. Inducing drought tolerance in plants: Recent advances. Biotechnol. Adv., 28:169-183.
Ashraf M, Foolad M. 2007. Roles of glycine betaine and proline in improving plant abiotic stress resistance. Environ. Exp. Bot., 59(2):206-216.

Bakalova S, Nikolova A, Nedeva D. 2004. Isoenzyme profiles of peroxidase, catalase and superoxide dismutase as affected by dehydration stress and ABA during germination of wheat seeds. J. Plant Physiol., 30(1):64-77.

Baloĝlu MG, Kavas M, Aydin G, Öktem HA, Yücel AM. 2012. Antioxidative and physiological responses of two sunflower (Helianthus annuus) cultivars under PEG-mediated drought stress, Turk. J. Bot., 36:707-714.

Beers Jr RF, Sizer IW. 1952. A spectrophotometric method for measuring the breakdown of hydrogen peroxide by catalase. J. Biol. Chem., 195:133-140.

Benavente-Garćia O, Castillo J, Lorente J, Ortũno A, Del Río JA. 2000. Antioxidant activity of phenolics extracted from Olea europaea L. leaves. Food Chem., 68:457-462.

Bradford MM. (976. A rapid and sensitive method for the estimation of microgram quantities of protein utilizing the principle of protein-dye binding. Anal. Biochem., 72:248-254.

Breton C, Gil A, Wargnier J, Serieys H, Berville A. 2012. Transfer of architectural traits from perennial Helianthus mollis Lam. to sunflower $(H$. annuus L.) and localization of introgression. Euphytica, 186:557-572.

Breton C, Serieys H, Berville A. 2010. Gene transfer from wild Helianthus to sunflower: topicalities and limits. Oléagineux, Corps Gras, Lipides, 17:104-114.

Cakmak I, Strbac D, Marschner H. 1993. Activities of hydrogen peroxide-scavenging enzymes in germinating wheat seeds. J. Exp. Bot., 44(1):127-132.

Claeys H, Inzé D. 2013. The agony of choice: how plants balance growth and survival under water-limiting conditions. Plant Physiol., 162(4):1768-1779.

Csiszár J, Gallé Á, Horváth E, Dancsó P, Gombos M, Váry Z, Tari I. 2012. Different peroxidase activities and expression of abiotic stress-related peroxidases in apical root segments of wheat genotypes with different drought stress tolerance under osmotic stress. Plant Physiol. and Bioch., 52:119-129.

Diaz-Zorita M, Duarte G, Plante E, Fernandez M. 2003. El cultivo de girasol. Asociacion Argentina de Girasol:10. Bs. As, Argentina. doi: 10.1002/9783527665334.fmatter

Faure N, Serieys H, Berville A, Cazaux E. 2002. Occurrence of partial hybrids in wide crosses between sunflower (Helianthus annuus) and perennial species $H$. mollis and $H$. orgyalis. Theor. Appl. Genet., 104:652-660.

Foyer CH, Noctor G. 2005. Oxidant and antioxidant signaling in plants: a re-evaluation of the concept of oxidative stress in a physiological context. Plant Cell Environ., 29:1056-107.

Giannopolitis CN, Ries SK. 1977. Superoxide dismutases I. Occurrence in higher plants. Plant physiol., 59(2):309-314.

Griveau Y, Serieys H, Cleomene J, Belhassen E. 1998. Field evaluation of sunflower genetic resources in relation to water supply. Czech. J. Genet .Plant Breed., 34:11-16.

Gunes A, Pilbeam DJ, Inal A, Coban S. 2008. Influence of silicon on sunflower cultivars under drought stress, I: Growth, antioxidant mechanisms, and lipid peroxidation. Communications in Soil Science and Plant Analysis, 39(1314):1885-1903.

Guo Z, Ou W, Lu S, Zhong Q. 2006. Differential responses of antioxidative system to chilling and drought in four rice cultivars differing in sensitivity. Plant Physiol. and Biochem., 44(11):828-836.

Hegarty MJ, Barker GL, Brennan AC, Edwards KJ, Abbott RJ, Hiscock SJ. 2008. Changes to gene expression associated with hybrid speciation in plants: further insights from transcriptomic studies in Senecio. Phil. Trans. R. Soc. B., 363:3055-3069 doi:10.1098/rstb.2008.0080.

Hoagland DR, Arnon D. 1950. The water-culture method for growing plants without soil, California Agricultural Experiment Station Circular, 347:1-32. 
Imlay JA. 2003. Pathways of oxidative damage. Annu. Rev. Microbiol., 57(1):395-418.

Kahkonen MP, Hopia AI, Vuorela HJ, Rauha JP, Pihlaja K, Kujala TS. 1999. Antioxidant activity of plant extracts containing phenolic compounds. J. Agric. Food Chem., 47:3954-3962.

Kaya MD, Okçu G, Atak M, Çikil Y, Kolsarici Ö. 2006. Seed treatments to overcome salt 17 and drought stress during germination in sunflower (Helianthus annuus L.), Eur. J. Agron., 24:291-295.

La Duke JC. 1982. Revision of Tithonia. Rhodora, p.453-522.

Lin $\mathrm{CC}$, Kao $\mathrm{CH}$. 2000. Effect of $\mathrm{NaCl}$ stress on $\mathrm{H} 2 \mathrm{O} 2$ metabolism in rice leaves. Plant Growth Regul., 30(2):151-155.

Marcińska I, Czyczyło-Mysza I, Skrzypek E, Filek M, Grzesiak S, Grzesiak MT, Quarrie SA. 2013. Impact of osmotic stress on physiological and biochemical characteristics in droughtsusceptible and drought-resistant wheat genotypes. Acta Physiol. Plant., 35(2):451-461.

McKersie BD, Leshem YY. 1994. Stress and Stress Coping in Cultivated Plants. Kluwer Academic Publishes, Dordrecht. pp. 256

Meloni DA, Oliva MA, Martinez CA, Cambraia J. 2003. Photosynthesis and activity of superoxide dismutase, peroxidase and glutathione reductase in cotton under salt stress. Environ. Exp. Bot., 49(1):69-76.

Michel B., Kaufmann M. 1973. The osmotic potential of polyethylene glycol 6000. Plant Physiol., 51(5):914-916.

Mittler R. 2002. Oxidative stress, antioxidants and stress tolerance. Trends Plant Sci., 7:405-410.

Nakano Y, Asada K. 1981. Hydrogen peroxide is scavenged by ascorbate-specific peroxidases in spinach chloroplasts. Plant Cell Physiol., 22:867-880.

Neill S, Desikan R, Hancock J. 2002. Hydrogen peroxide signalling. Curr. Opin. Plant Biol., 5(5):388-395.

Oraki H, Khajani FP, Aghhlikhana M. 2012. Effect of water deficit stress on proline contents, soluble sugars, chlorophyll and grain yield of sunflower (Helianthus annuus L.) hybrids, Afr. J. Biotech., 11:164-168.

Pan Y, Wu LJ, Yu ZL. 2006. Effect of salt and drought stress on antioxidant enzymes activities and SOD isoenzymes of liquorice (Glycyrrhiza uralensis Fisch). Plant Growth Regul., 49(2-3):157-165.

Petcu E, Pâcureanu JM. 2011. Developing drought and broomrape resistant sunflower 17 germplasms utilizing wild Helianthus species. Helia, 34:1-8

Pfeffer H, Dannel F, Römheld V. 1998. Are there connection between phenol metabolism, ascorbate metabolism and membrane integrity in leaves of boron-deficient sunflower plants? Physiol. Plantarum, 104:479-485.

Pietta PG. 2000. Flavonoids as antioxidants. J. Nat. Products, 63:1035-1042.

Plewa MJ, Smith SR, Wagner ED. 1991. Diethyldithiocarbamate suppresses the plant activation of aromatic amines into mutagens by inhibiting tobacco cell peroxidase. Mutation Res., 247:57-64.

Rauf S. 2008. Breeding sunflower (Helianthus annuus L.) for drought tolerance, Commun. Biom. 16 Crop Sci., 3:29-44.

Reyes-Valdés MH, Gómez-Martínez M, Martínez O, Godínez FH. 2005. Intergeneric hybrid between cultivated sunflower (Helianthus annuиs L.) and Tithonia rotundifolia (Mill) Blake. Helia, 28 (43):61-68.

Riesenberg RH, Willis JH. 2007. Plant speciation. Science, 317:910-914.

Rönicke S, Hahn V, Horn R, Grone I, Brahm L, Schnabl H, Friedt W. 2004. Interspecific hybrids of sunflower as a source of Sclerotinia resistance. Plant Breed., 123:152-157.

Ŝcorić D. 2009. Sunflower breeding for resistance of abiotic stresses. Helia, 32:1-16.
Singh D, Malik CP. 2012. Assesment of genetic diversity in Verbesina encelioides populations using randomly amplified polymorphic DNA (RAPD) markers. Intern J Scientific \& Technol. Res., 1(4):1-8.

Stancheva I, Geneva M, Yonova P, Markovska YU. 2011. Accumulation of $\mathrm{Cd}, \mathrm{Pb}$ and $\mathrm{Zn}$ in Tribulus terrestris L.grown on industrial polluted soil and plant antioxidant response. Adv. Environ. Biol., 5:300-306.

Tepe B, Sokmen M, Akpulat HA, Sokmen A. 2006. Screening of the Antioxidant Potentials of Six Salvia species from Turkey. Food Chem., 95:200-204.

Turhan H, Baser I. 2004. In vitro and in vivo water stress in sunflower (Helianthus annuus L.). Helia, 27 (40): 227-236.

Tuteja N, Gill SS, Tuteja R. (eds), 2012. Front Matter, in Improving Crop Productivity in Sustainable Agriculture, Wiley-VCH Verlag GmbH \& Co. KGaA, Weinheim, Germany.

Urbanek H, Kuzniak-Gebarowska E, Herka K. 1991. Elicitation of defense responses in bean leaves by Botrytis cinerea polygalacturonase. Acta Physiol. Plant., 13:43-50.

Vassilevska - Ivanova R, Tcekova Z, Lidansky T. 1999. Intergeneric hybridization of cultivated sunflower Helianthus annuиs L. with Tithonia rotundifolia Blake. Compt. Rend. ABS, 52 (1-2): 93 96

Vassilevska-Ivanova R, Lidansky T, Tcekova Z. 2000. Observations on the seedling growth in some wild Helianthus genotypes. Compt. Rend. Acad. Bulg. Sci., 53:77-80.

Vassilevska - Ivanova R, Tcekova Z. 2002. An attempt for hybridization Helianthus x Verbesina. Compt. Rend ABS, 55 (9): $99-104$.

Vassilevska-Ivanova R, Naidenova N. 2005. Intergeneric hybridization between cultivated sunflower and Asteraceae genera: Helianthus annuus $x$ Echinacea purpurea. Compt. Rend. ABS, 58 (6): $729-734$.

Vassilevska-Ivanova R, Kraptchev B, Stancheva I, Geneva M. 2013. A compact sunflower line produced after cross Helinathus annuus $\times$ Verbesina encelioides. Cent. Eur. J. Biol., 8 (5): 492498.

Vassilevska-Ivanova R, Kraptchev B, Stancheva I, Geneva M, Iliev I, Georgiev G. 2014a Utilization of related wild species (Echinacea purpurea) for genetic enhancement of cultivated sunflower (Helianthus annuus L.). Turk. J. Agric. For., 38 (1): $15-22$.

Vassilevska-Ivanova R, Shtereva L, Kraptchev B, Karceva T. 2014b. Response of sunflower (Helianthus annuus L) genotypes to PEG-mediated water stress. Cent. Eur. J. Biol., 9 (12):12061214.

Vassilevska-Ivanova R, Kraptchev B, Shtereva L. 2015. An intergeneric hybrid line produced after cross Helianthus annuus x Echinacea purpurea. Genet. Resour. Crop Evol. ISSN 09259864 DOI 10.1007/s10722-015-0281-z.

Wagner WL, Herbst DR, Sohmer SH. 1990. Manual of the Flowering Plants of Hawaii, Volume 1. University of Hawaii Press, Bishop Museum Press.

Xiao XW, Xu X, Yang F. 2008. Adaptive Responses to Progressive Drought Stress in Two Populus cathayana Populations. Silva Fennica, 42(5):705-719.

Zhishen J, Mengcheng T, Jianming W. 1999. The determination of flavonoid contents in mulberry and their scavenging effects on superoxide radicals. Food Chem., 64:555-559.

Zlatanov M, Angelova-Romova M, Antova G, Ivanova E, Damyanova B, Momchilova S, Marecov I. 2008. Phosholipid composition in oils from Bulgarian varieties of sunflower. Plovdiv University „Paisii Hilendarski“ - Bulg Sci Papers Chemisry, 36 (5): 105-110. 